\title{
THE BRITISH MILITARY HOSPITALS IN MACEDONIA DURING THE FIRST WORLD WAR
}

\section{Vladimir Cvetkovski}

English Department, Faculty of Philology Blaže Koneski, Ss Cyril and Methodius University, Skopje, R. Macedonia

Corresponding Author: Vladimir Cvetkovski, English Department, Faculty of Philology Blaže Koneski, Ss Cyril and Methodius University, 10 Vodnjanska str., Skopje, R. Macedonia; E-mail: marijacvet@ gmail.com

\begin{abstract}
The paper focusses its attention to the medical work of the British Military hospitals stationed in Macedonia during the First World War, the surgical work carried out under very heavy conditions in improvised operating theatres as well as the treatment of the wounded and sick solders brought from the battlefields on the Macedonian Front.
\end{abstract}

Keywords: The First World War, The Macedonian Front, Skopje, Dr. McLaren, Lady Paget, Scottish Women's Hospitals, Ostrovo.

The First World War had brought many British subjects to the Macedonian Front. Beside the soldiers who fought in the units of the allied forces, there were volunteers who came with the medical units which were sent to the Balkans by the British Red Cross, The Scottish Women's Hospitals and the Serbian Relief Fund. Field hospitals were stationed along the main battle lines in Serbia and Macedonia: Mladenovac, Kragujevac, Skopje, Bitola, Ostrovo, Voden etc.

The declaration of war on August $4^{\text {th }} 1914$ caused ferment in Britain. Recruiting offices and voluntary organizations sprang up all over the country and men, some mere boys, and women, enthusiastically enlisted. Among those were significant persons from the British cultural and public life, artists, theatre actors, writers and other persons from the high ladder of the social life. Already on the 20th August 1914 Dr. Elsie Inglis propagated the establishment of a hospital and the Scottish suffrage offices in Edinburgh became the Scottish Women's Hospitals, where not only Scottish, English, Irish and Welsh women served in their units, but many came from Australia, New
Zealand and elsewhere (Krippner 1980: 30). This is particularly true of the composition of the 'America' unit, so named because of the funds raised in America stationed at Lake Ostrovo in Macedonia, where in 1917, beside the women doctors from Australia, Dr. Bennet, Dr. Hellen Saxton, Dr. De Garris and others there were orderlies and other personnel from Britain and elsewhere. Among those was the Australian writer Miles Franklin who worked as an assistant cook. She left a memorable description of the life and work at the hospital in her unpublished work Ne mari ništa - It Matters nothing, the manuscript of which is curated at Mitchel Library in Sydney. Many men and women were recruited by the SCWH and sent to the Front in Macedonia.

The British Red Cross was also engaged in sending medical personnel to the Balkan Front, right after the first engagements started. Among the first to arrive in Serbia was the Field Hospital led by Mrs. St. Clair Stobbard, which was stationed near Kragujevac, the activity of which is impressively described in her work The Flaming Sword over Serbia. In it she describes in details not only the medical work in the hospi- 
tal but also the tragic Golgotha of the retreat of the Serbian Army across the frozen mountains of Albania.

By mid-November 1914 the First Serbian Relief Fund Unit commanded by Lady Leila Paget arrived in Skopje, Macedonia, to establish a fine 600 hundred bed hospital on a hill outside Skopje. The Unit had appropriated the 'Gymnasium', a fine block of buildings used primarily as a technical school and capable of accommodating three hundred beds.

A week after the arrival of Lady Paget's Unit the medical unit sent by the British Red Cross led by Dr. McLaren, Canadian Scotsman, 'the chief' as they called him, arrived in Skopje.

Very soon the Serbian Relief Fund was launched at the head of which stood Her Majesty the Queen as a Patroness, supported by distinguished public figures of the British Society: The Lord Bishop of London, President of the SRF; Vice presidents were: H. E. Cardinal Bourne, The Earl Courzon of Kedleston, The Lord Bishop of Oxford, Rt. Hon. H. H. Asquith, M. P., Rt. Hon. A. Bonar Law M. P., Rt. Hon. Austen Chamberlain, M. P., Rt. Hon. Winston Churchill, Rt. Hon. Herbert Samuel, M. P., Rt. Hon. D. Lloyd George, M. P., Madame Gruitch, Rev. G. Campbell Morgan, D. D., Rev. F. B. Mayer, D. D., Mr. Noel Baxton, M. P., Chairman: The Lord Henry Cavendish Bentinck, M. P., Vice Chairman: Mr. Glynne Williams, Committee: The Lord Charnwood, The Lord Fitzmaurice, The Lord Haversham, The Hon. Bernard Wise, Sir Edward Boyle Bart, Sir Arthur Evans LL D., F. R. S., Sir Valentine Chirol, Hon. Lady Whitehead, The Lady Rodney, Lady Boyle, Lady Grogan, Lady Paget,
Mrs. Noel Baxton, Mrs Bertram Christian, Madame Christich, Mrs. James Currie, Miss Aubrie Fletcher, Mrs. Fry, Mrs. H. R. Gotto, Mrs. Arthur Harrison, Mrs. Grice Hutchinson, Dr. Elsie Inglish, Miss McQueen, Mrs. Masterman, Mrs. Scaramanga Ralli, Mrs. Seton Watson, Mrs. Carrington Wilde, Mr. W. A. Albright, Mr. P. Alden, M. P., Mr. Jas. Berry, F. R. C. S., Mr. H. N. Brailsford, Mr. R. M. Burrows, D. Litt., Mr. Bertram Cgristian, Rev., Percy Dearmer, D. D., Mr. G. Hanrahan, Mr. C. L. Graves, Mr. Jpynson-Hicks, M. P., Mr. James F. Hope, M. P., Mr. Hugh Law, M. P., Mr. R. O. Moon, M. D. F. R. C. B., Mr. H. E. Morgan, Mr. T. P. O’Connor, M. P., Mr. J. O'Grady, M. P., Mr. A. M. Scott, M. P., Mr. St. Loe Stratchey, Mr. A. G. Symonds, Mr. G. M. Trevelyan; Treasurer: Rt. Hon. The Earl of Plymonth; Hon. Secretary: Mr. R. W. Seton-Watson, D. Lit.; Hon. Financial Secretary: Mr. F. C. Lindo; General Secretary Mr. F. M. Scott; Bankers: London County \& Westminster Bank Ltd.; Hon. Auditors: Messrs, Cole, Dickin \& Hills.

Lady Paget's Hospital was organized according to the best medical standards capable of treating not only wounded soldiers but also sick soldiers and patients from the local population especially after the outbreak of the typhoid epidemics. In her Report entitled 'With Our Serbian Allies', Lady Paget beside the medical work carried out in the hospital she describes the political situation in the city, and the tensions that occurred when the Bulgarians and the Germans occupied the city. At the end of the Report she presents a list of the whole personnel of the hospital that elicits the structure and the solid organization of her Unit. We present it here with no changes.

\begin{tabular}{|c|c|}
\hline \multicolumn{2}{|c|}{$\begin{array}{l}\text { LADY PAGET'S UNIT IN SKOPJE No. II } \\
\text { MEDICAL STAFF }\end{array}$} \\
\hline Medical Director & Surgeon \\
\hline $\begin{array}{l}\text { T. GWYNNE MAITLAND, Esq., M A., B.Sc., C.M., D. } \\
\text { Phil. }\end{array}$ & Dr. M. SEEDORF (Danish). \\
\hline Surgeon-in-chief & Assistant Surgeon. \\
\hline $\begin{array}{c}\text { FERGUS ARMSTRONG, Esq., M. D., F.R.C.S. } \\
\text { Assistant Surgeon. }\end{array}$ & $\begin{array}{l}\text { Dr. ERIK HIMMELSTRÜP (Danish). } \\
\text { Physicians }\end{array}$ \\
\hline PERCY WALLICE, Esq., M.R.C.S., L.R.C.P. & Dr. A. F. CORNELIUS (American). \\
\hline Physiciar & Dr. ERLE D. FORREST (American). \\
\hline R. M. MORISON, Esc & Dr. R. V. BROKOW (American). \\
\hline
\end{tabular}

CHANCERY STAFF

Secretary

Mr. EDGAR DAVIES.
Treasurer

Mr. T. E. MILLIGAN GRUNDY. 


\author{
Dispenser. \\ Mr. A. PATERSON \\ Radiographer \\ Mr. J. LAMB. \\ Anesthetists \\ Mr. IVAN CAMPBELL. \\ Mr. E. P. CHAPMAN \\ The following gentlemen were not official members of the Staff, but very kindly acted as voluntary \\ workers:- \\ Bacteriologist. \\ Sanitary Engineers. \\ Dr. T.H. PLOTZ (American). \\ Dr. OSBORN* (American). \\ Dr. GEORGE BAEHR \\ C. E. FOX, Esq.* \\ *Member of the American Red Cross Sanitary Commission.
}

\author{
LADY PAGET'S UNIT IN SKOPJE No. II \\ NURSING STAFF \\ Matron. \\ Miss LOUISA BALL.
}

Housekeeper.

Mrs. OLIVE JOURDAIN.

Masseuses.

Mrs. G. POLGREEN.

Mrs. ADA BARLOW.

BRITISH

Miss MABEL ATKINSON (N. Z.)

Miss MAUD BULLOCK.

Miss JEAN CALDOW.

Miss M. K. COLEMAN.

Miss T. CROMBLEHOLME.

Miss EVA E. EGERTON.

Miss I. GRAY.

Miss I. HUDSON.

Miss DORA JOHNSON.

Miss G. LLYN JONES.

Miss ALICE LEVESON.

Miss AGNES MANN.

Miss ROSALIE MANSELL.

Miss C. B. MELLIS.

Miss M.T. O’NEILL

Miss J. S. RANKIN.

Miss BEATRICE ROBINSHAW.

Miss S. A. ROUND.

Miss ETHEL SCAMMELL.

Miss M. M. SHARPIN.

Miss M. E. SKERTCHLEY.

Mrs. PERCY WALLICE

BRITISH.

Storekeeper

Mr. C. R. COOKE-TAYLOR.

Chauffeur and Carpenter

Mr. J. L. GASKING

Mr. H. C. M. HARDINGE

Lady Paget and her staff remained in Skopje even after the entry of the Bulgarians and Germans and continued to treat the wounded soldiers.

\section{SISTERS}

AMERICAN

Miss R. PARSONS.

DANISH

Miss HENNY GRAVESEN.

Miss JOHNNY HENDRICKSEN.

Miss THEKLA MADSEN.

Miss SIGNE MÖLLER.

Miss MINNA WIFSTRAND.

DUTCH

Miss WILLY FORBES-SCHMELTZER.

Miss MARIE VAN OYEN.

Miss VAN DER VEEN.

FRENCH

Mlle VILLEMON.

\section{ORDERLIES}

AMERICAN.

Mr. W. W. EATON.

Mr. F. KLEPAL.

Mr. T. B. LOGAN.

Mr. D. PETERS.

Mr. R. SHELLENS

Mr. M. A. TANCOCK.

... The whole hospital staff was working at high pressure, bringing the wounded and washing and dressing their wounds. The corridors and the staircases were soon full to 
excess; we therefore placed forms at the back under cover of the buildings, on which they sat with their ghastly wounds, waiting till could be attended to. During the battle we dressed the wounds of many hundreds of Serbians, but kept actually in the hospital only about two hundred. I cannot praise too highly the cool, practical way in which the whole staff went about the work.

Our Austrian prisoner orderlies had always won my admiration by their loyalty and devotion to duty, but never did their behavior merit our respect than now.

Lady Paget: With Our Serbian Allies, pp. 32

The British Red Cross Unit led by Dr. McLaren consisted of six doctors: Dr. J. Johnston Abraham, Dr. Barkley; the names of the others are not given, each with two orderlies. Later on to their group of doctors was added a Russian woman doctor presented in his book as The Little Red (haired) Woman. The names of only three orderlies are rendered: Anthony, Steve, James, Later on the group of orderlies was enlarged with several prisoners of war some of them Czechs, from the Austrian army.

Dr. J. Johnston Abraham, an Irishman - Britisher as he called himself is the author of a fascinating work, a kind of a diary which is more than that - My Balkan Log in which he describes not only the medical work and complicated operations performed in their hospital but also it renders a vivid description of the life in the city, its cultural monuments, the customs of the local ethno culture and, we may say, it is the first novel of Skopje.

Here we shall focus mainly to the work in the hospital.

“... The hospital was stationed in three buildings all close together, which had originally been store houses for tobacco, close to the railway station. The largest 'Number One' had space accommodation for six hundred beds, the other two for approximately three hundred each. 'Number One' had three great floors, each containing two hundred beds. It was lit feebly with a few electric lights on each floor; but there was no water of any sort laid on, and absolutely no inside sanitary accommodation."

My Balkan Log: p. 41

'... December the first was a red-letter day in our calendar, for on that day we started a real operating theatre - the theatre for which, ever since our arrival, our Chef had been working.
At any rate we had a theatre which really looked as theatre, and here the Chief, Barkley and I spent two happy months very busily until the great blight came.

The next day we had a fresh convoy from the front; and now our theatre was in working order, the Serbian officials began to give us what they called more serious cases. Instead of wounds of limbs we began to get head injuries, gunshots wounds of chest, and more and more compound fractured femur. The number of abdominal injuries that passed through our hospital then and afterwards was surprisingly few.

... Each new patient came, or was brought, to one of half dozen operating tables to be examined; the field dressing was taken off, and the wounds cleaned up by one or other of the assistants. Then the Major came along, and a rapid diagnosis was made. Sometimes he would pass on quickly, sometimes stop and ask a question. Every now and again he would run his fingers over an arm, leg or chest, feel a bullet or a piece of shrapnel, grip it between his fingers, and with a rapid cut of a knife turn it out without bothering about any anesthetic. It was fierce, rapid medieval surgery; and the patient stood it without even a murmur. They were all so quiet, so apathetic, so very tired.

Ibid: pp. 45-46.

... Every day now we had a fresh convoy of wounded Serbs, Austrians. The Austrian soldiers were mixed. They had Magyars (Hungarians), Czechs, Slovaks, Slovenes, Poles, Dalmatians, Croats, Jews, Romanians, Italians and Austrians proper among themselves.

Soon the first cases of typhus occurred in the hospitals in Skopje and it spread throughout the city. During the winter campaign it became epidemic and we had several thousand cases through our hands in the first three months. Recurrent fever, the Serbs, following Continental nomenclature, call it Typhus Recurreus to distinguish it from Typhus Abdominalis (our Typhoid Enteric).

It is caused by a spirillum and runs a very typical course. There is high fever, intense prostration, and some delirium lasting for about a week. Then comes a rapid fall of temperature, and a week when the temperature registers normal or subnormal. This is followed by a second and sometimes a third similar rise and fall till the patient is reduced to a skeleton, almost too weak to turn in bed. 
Among ourselves, at first, we label it 'Uskubitis', before we recognized the cause. Eventually, we simply called it 'IT'.

Ibid: pp. 75.

The first cases of typhus occurred in some of Skopje hospitals such as Polymesis (Polumesec - Half-moon); soon it spread throughout the city and people were dying in great numbers.

Two ox-wagons lumbering along the main street, each with an armed man in front, caught my eye; and as they passed I glanced casually at the contents. There were some twenty bodies, ten in each wagon, coffinless, carelessly wrapped in blankets.

Men were dying in such numbers; the carpenters could not cope with the demand for coffins. People were getting more and more frightened. Even the Tzigans began to refuse to handle the bodies.

Ibid: pp. 245

The first British Field Hospital for Serbia reached Salonika on April 15, 1915. Beside the medical staff there were civilians engaged as assistants in nonmedical work, among those were Alice and Claude Askew who joined the unit as writers but 'we were prepared to turn our hands to odd jobs if called upon to do so'.

The unit consisted of some twenty six individuals all together. Surgeons, dressers, orderlies, chauffeurs, a staff of most capable nurses, a cook, a washwoman, an interpreter - and a dog.

They are the authors of The Stricken Land in which they described not only the medical work carried out in Skopje and later on at Pirot where they moved later on, but also the tragic retreat of the Serbian Army on their Via Dolorosa through Montenegro and Albania to Corfu where those who survived were transported to recover.

The staff of our unit had been carefully selected by the Committee in London. The organizer of the enterprise was Dr. J. Hartnell Beavis, whose name was already known in connection with similar work in Belgium. With him - his right-hand man - was Mr. Gerald Sim who had been in Belgium too, where he had got his laurels as an expert chauffeur. Our Chief surgeon was Mr. Fergus Armstrong, F. R. C. S. who had given up an important post to join us and a more able operator or pleasant companion could not have been desired. Alas, he was not with us at Pirot, having undertaken during the slack period that preceded the Bulgarian outbreak to work for Lady Paget at Skopje. A physician we had Dr. G. Landsborough Findley, who with his wife, Lady Sybil - one of our nurses. The unit consisted of some twenty-six individuals altogether surgeons, dressers, orderlies, chauffeurs, a staff of most capable nurses, a cook a washwoman, an interpreter, and a dog.

The Stricken Land, pp. 22-23.

The next British hospital sent to Macedonia was the one sent by the Scottish Women's Hospital known as "American Unit" because the money for the original outfit was a gift of the people of the United States. It was stationed near Lake Ostrovo on the Macedonian Front in August 1916, where the bloodiest battle had been fought on the Mount of Kaymakchalan in 1917.

The hospital camp was situated some three hundred miles of Ostrovo and the railway station. The ward tents were twenty in number and passage ways connecting tents had been provided for them. Each tent took ten beds and the hospital for two hundred; also there were X-ray tents, a clothing store etc.

Beside these there was dressing station up the hills where the first dressing of the wound of the wounded soldiers was performed ant the patients were transported to the hospital by ambulances driven by women drivers.

The medical staffs in the hospital were all women doctors: Dr. Bennet (the C. M.), Dr. Cooper (who had joined the unit from Australia), Dr. Lewis, Dr. Scott. Dr. Mancaster.

Details about the work of this hospital, the heavy fightings in the mountains on this part of the Macedonian Front are described in the work At the Serbian Front in Macedonia by E. P. Stebbing, a university professor from Edinburgh who served as a transport officer - as he explains - 'the job which Dame Fortune, flung to me after two years spent in attempting to persuade generals, colonels and even majors, to give me a temporary job on active service during the few months' leisure each year which a post in a University allows one'. (Stebbing: pp. 1)

As an eye witness Stebbing gives detailed description of the heavy military engagements on this side of the Macedonian Front. So this work is also of historical value as a document of what was going on at the battlefields in Macedonia during the Great War.

Here is a detail of what he had seen when he visited the place after one of the cruelest battle was over on the Mount of Kaymakchalan fought in 1917. 
... Here the damage done was terrific and both trenches and ground behind them are littered with dead Bulgars, whilst in many cases all signs of a trench are obliterated. There is one of these lines of trenches which are particularly hideous. Here a whole line of Bulgars was either mown down or killed by grass shells and lie in every conceivable position. At a distance they look as if they were asleep, but from their tattered clothing as one approaches one knows that their sleep is the sleep of death and that the death has been a violent and bloody one.

At the Serbian Front in Macedonia: p. 181

In the meantime the British military units arrived in Salonika as part of the Allied Forces whose soldiers were sent to the Macedonian Front; so the number of the British subjects stationed in Macedonia was considerable. Some of them never returned to their homes and remained to rest forever in their perpetual home that fate had ordained for them in the British Military Cemetery in Skopje. Inscriptions of the name, the unit in which they served and an occasional epitaph on the tombstone hide many stories of brave deeds achieved at Doyran and elsewhere on the Macedonian Front, buried there never to be told to posterity. French military cemeteries exist in Skopje and Bitola where soldiers of the French troops had been buried.

In Macedonia, particularly in Skopje crowds of English-speaking people walked in the streets of the city and its markets watching in bewilderment the medley of its population, the breath-taking beauty of the landscape, the grandeur of the old buildings, churches and monuments. On their way back home they picked up some artifacts from the place, such as pieces of folk costumes they had bought from the local peasants. Some of these might have been put aside or in attics since, for the successors, they had lost the significance and the endearment they had for the original owners who had carried them from afar as reminders of their great adventure in life. However, far more important for posterity are the works and the records they made in the years of the Great War in which they have described most vividly and in the most impressive way the major incidents of which they were not only eyewitnesses but active participants as well. Some of those narrations soar to the heights of the best examples of the English literary prose tradition which testifies to the great literary talent of their authors.

\section{REFERENCES}

1. Abraham, J. Jonston. My Balkan Log, Chapman \& Hall, Ltd, London, 1921.

2. Askew, Alice, Askew, Claude. The Stricken Land, Evelin Nash Company Limited, London, 1916.

3. Cvetkovski, Vladimir. Macedonia in the British Memoirs from the First World War, Јубилеен годишен зборник кн. II, Филолошки факултет, Skopje, 1996, p. 394-410.

4. Franklin, Miles. Ne mari ništa, It Matters Nothing Serbia as we saw it, Carbon transcript Vol. ML MSS. 445/4 Mitchell Library, State Library NSW.

5. Krippner, Monica. The Quality of Mercy - Woman at War Serbia 1915-18, David and Charles Newton Abbot, London, 1980.

6. Lady Paget: With Our Serbian Allies. Second Depart, Printed for private circulation.

7. Price, G. W. The Story of the Serbian Army, the Official Correspondent with the Allied Forces in the Balkans, Hodder and Stoughton, London, 1918.

8. Stebbing, E. P. At the Serbian Front in Macedonia, Illustrated with photographs by the author, John Lane, London, 1917.

Резиме

\section{БРИТАНСКИТЕ ВОЕНИ БОЛНИЦИ ВО МАКЕДОНИЈА ЗА ВРЕМЕ НА ПРВАТА СВЕТСКА ВОЈНА}

\section{Владимир Цветковски}

Катедра за англиски јазик и книжевност, Филолошки факултет „Блаже Конески“, Универзитет „Св. Кирил и Методиј“, Скопје, Р. Македонија

Статијата се осврнува на медицинската дејност на британските воени болници стационирани во Македонија за време на Првата светска војна, особено на хируршките зафати вршени под многу тешки услови во импровизирани операциони сали, како и лекувањето на ранетите и болните војници што се испраќаa од боиштата на Македонскиот фронт.

Клучни зборови: Прва светска војна, Македонски фронт, д-р Мек Ларен, Леди Пеџет, Болница на Шкотланѓанките, Остров 